\title{
Managerial Ownership, Leverage and Dividend Policies: Empirical Evidence from Vietnam's Listed Firms
}

\author{
Duc Hong Vo ${ }^{1} \&$ Van Thanh-Yen Nguyen ${ }^{2}$ \\ ${ }^{1}$ Economic Regulation Authority, Perth, Australia \& Open University, Ho Chi Minh City, Vietnam \\ ${ }^{2}$ Open University, Ho Chi Minh City, Vietnam \\ Correspondence: Duc Hong Vo, Economic Regulation Authority, Perth, Australia \& Open University, Ho Chi \\ Minh City, Vietnam. E-mail: duc.vo@erawa.com.au
}

Received: March 27, 2014

Accepted: April 14, 2014

Online Published: April 25, 2014

doi:10.5539/ijef.v6n5p274

URL: http://dx.doi.org/10.5539/ijef.v6n5p274

\begin{abstract}
The purpose of this paper is to examine the interrelationship among managerial ownership, leverage and dividend policies. The analysis is performed using three-stage least squares (3SLS) estimation on a sample of 81 listed firms on HCM City Stock Exchange (HOSE) during the period 2007-2012. The empirical results indicate that managerial ownership has a negative relationship with leverage. This finfing is supported by Agency Theory. Also, the results provide strong support for Pecking Order Theory, which suggests that there is a negative relationship between leverage and dividend. However, contrary to expectations, managerial ownership is found to have positive impact on dividend. It means that companies with higher levels of managerial holdings are consciously choosing higher level of dividends.
\end{abstract}

Keywords: managerial ownership, leverage, dividend, interrelationship, 3SLS, Ho Chi Minh City's stock exchange

\section{Introduction}

The role of managers is to maximize shareholder's wealth. However, managers who do not have a significant ownership in the firm may have incentives to make decisions which are not at the best interest of shareholders. Such conflicts will lead to agency problem and incur significant costs. Corporate governance has emerged as an important issue for Vietnamese-listed firms in the broader context of financial development. Most Vietnamese-listed firms were privatized from State-Owned Enterprises. The government is generally a major shareholder after the firms go public and managers are delegated to act on their behalf. As a result, it is expected that managers of these firms will act on the interest of the controlling shareholders. Nevertheless, in recent years, there have been a number of company scandals from corporate governance failures involving in managerial opportunism. Eventually, achieving the goal of maximizing the value of the firm often becomes unattainable.

Previous studies suggest that corporate ownership structure and financial policies can affect firm's performance and value by mitigating agency costs of the firm. A large body of literature indicates that insider ownership helps aligning managerial interests with those of the external shareholders (Jensen, 1986; Fama, 1980). Debt holders and related monitoring tools are also considered important mechanisms for controlling managerial behavior and mitigating the agency problems (Jensen \& Meckling, 1976; Rozeff, 1982; Easterbrook, 1984; Stulz, 1990; Bathala, Moon, \& Rao, 1994). Given the array of internal monitoring tools that can be used to resolve agency problems, owners of the firms can adopt a combination of these policies. This also implies that a firm's managerial ownership, leverage and dividends might be simultaneous and there is substitution effects between the three financial variables directly related to each other (Jensen, Solberg, \& Zorn, 1992; Chen \& Steiner, 1999; Crutchley, Jensen, Jahera, \& Raymond, 1999).

Prior empirical studies have been conducted to mainly investigate each policy independently in the context of Vietnam. In light of the direct relationships among these policies, empirical studies on this topic are limited in the Vietnamese context. As such, this paper empirically analyzes the relationship between a firm's managerial ownership, leverage and dividend policies. According to Kim, Rhim and Friesner (2007), this clearly has the potential of creating an endogeneity problem and thus the use of simultaneous equation models is essential in the empirical test. These equations are estimated using the Three stage least squares (3SLS) technique and each 
equation includes each of the three policy choices. To these equations, several explanatory variables are also added to capture real attributes of firms such as (i) free cash flow, (ii) firm size, (iii) growth, (iv) liquidity, (v) profitability and (vi) tangibility.

The finding of research is expected to make several contributions to the existing literature. First, it provides evidences to reinforce the notion of simultaneously determined corporate monitoring forces (managerial ownership, debt and dividends). Second, it contributes to the growing number of papers using 3SLS estimation as an alternative to ordinary least squares (OLS) regression. The basic assumption of OLS estimator is that exogenous variables are uncorrelated to the residual terms. Therefore, in terms of explaining causality among these policies, the OLS produces biased and inconsistent estimates. Lastly, it contributes additional explanations on Agency Theory and Pecking Order Theory in the context of the Vietnamese financial market.

The remainder of this paper is structured as follows. Following this Introduction, Section 2 presents a review of the relevant literature, covering the fundamental theoretical discussions that aim to consider that the managerial ownership, financial leverage and dividend payout are interdependent. It concludes with the specification of the main hypotheses to be tested. Section 3 describes the sample of firms, variable definitions, data sources, and the methodology. Section 4 reports the results of the empirical tests and Section 5 concludes the paper with policy implications.

\section{Literature Review and Hypothesis Development}

Examining the possible relationship between managerial ownership, leverage and dividend policy requires some theoretical platform. The main theories on these issues are briefly discussed including (i) agency theory, (ii) signaling theory and (iii) pecking order theory. This section concludes with a discussion of the interrelationship among managerial ownership, financial leverage and dividend policy.

\subsection{Agency Theory}

According to the agency model of the firm initiated by Jensen and Meckling (1976), the modern corporate organization is subject to agency conflicts arising from the separation of ownership and management in the firm. In this setting, managers have an incentive to consume excessive perquisite rather than to maximize shareholders' wealth. Agency theory suggests several mechanisms to mitigate agency problem, three of which are relevant to this study. One mechanism suggested by Jensen and Meckling (1976) is to increase the ownership of the managers in the firm, thus forcing managers to bear the wealth consequences of their actions. Consequently, managerial ownership can serve as governance mechanism in aligning the interest of mangers with that of the external shareholders. Sundaramurthy and Lewis (2003) emphasized the role of managerial ownership in controlling managerial opportunism in the firm. In addition, Vo and Phan (2013) found that the increase in managerial ownership will improve the performance of firms in Vietnam. However, when managers hold a significant portion of a firm's equity, an increase in ownership may prevent them from being replaced or punished for their improper decision and this results in managerial entrenchment. Once entrenched, managers are likely to consume more perquisites or to reduce the firm's risky investment opportunities to protect their own interests (Morck, Shleifer, \& Vishny, 1988).

The second mechanism to reduce agency cost is to force the firm to use leverage or debt financing (Rozeff, 1982; Easterbrook, 1984; Jensen, 1986). The increase of debt will lead to risk of corporate bankruptcy and job loss that further motivate managers to use the cash flow efficiently and reduce their perks. In addition, with high debt, managers are under pressure of investing profitable projects to generate cash flow to make periodic payments of interest and principal.

Rozeff (1982) and Easterbrook (1984) make a similar argument that dividend payment can be used as an internal mechanism to reduce agency cost. Paying larger cash dividends increases the chance that external equity capital will have to be raised to finance existing and future investment. When the firm issues more new securities, managers are monitored by capital market (Emery \& Finnerty, 1997). This monitoring induces managers to act more in line with shareholders' interests.

\subsection{Signaling Theory}

Signaling theory focuses upon the asymmetric information between insiders, as managers; and outsiders, as shareholders and banks. Ross (1977) assumes that managers have better knowledge of firm's investment opportunities than outsiders. Outsiders usually face a great deal of information asymmetry concerning the real value of firm's present and future investment. Therefore, outsiders consider any change in capital structure and dividend policy as signals of the firm's performance. If managers decide to add more debt into capital structure, outsiders will interpret it as a signal of higher future cash flow (Ross, 1977). However, if managers decide to 
finance the firm by issuing new equity, it signals that firm has unfavorable prospects and attempts to look for new investors to share the losses. Thus, the higher level of leverage shows the higher confidence of manager in the firm's performance in the future.

Similarly, dividends are also suggested as generating a positive signal to outsiders because only firms with high level of profitability in the future can issue dividends. Consequently, the higher are dividends relative to retained earnings, the stronger is the expectation of managers on firm's future income as a means of maintaining the current dividend payout level.

In addition, Leland and Pyle (1977) argued that the equity held by managers can serve as substitute signal of firm quality. Managers will only be willing to invest considerable holdings in firm's stocks when they are convinced that the firm has delightful prospects in the near future (Busenitz, Fiet, \& Moesel, 2005).

\subsection{Pecking Order Theory}

Pecking Order Theory explained that firms follow a hierarchy of financial decisions when establishing its capital structure. According to this theory, a profitable firm is more likely to finance projects from the internal funds rather than external funds (Myers \& Majiluf, 1984; Friend \& Lang, 1988; Rajan \& Zingales, 1995). Initially, firms first finance projects with the retained earnings. If the retained earnings are not sufficient, the firms go for debt and if further financing is required, the last option for the firm is to issue equity. The retained earnings is preferred over debt and equity because retained earnings almost incur no flotation costs and require no disclosure of the firm's financial information. On the contrary, the external sources are used for financing like issuing of new shares may incur very high cost (Myers, 1977). Since this is expensive, it may lead to lower dividends.

The above discussions on the three theories imply that managerial ownership, debt and dividend policies are all useful in mitigating agency costs and resolving information asymmetry of a firm. However, these mechanisms are used with the costs. Excessive level of ownership held by managers may lead to entrenchment problems. As managers become entrenched, they require increasing amount of compensation (Morck et al., 1988). The use of debt financing may result in substantial costs including bankruptcy costs and debt agency costs incurred as debt holders have to bear higher risk. Additionally, similar to the use of debt, dividend payout policy is not costless. Since external capital is raised to pay for the dividends, substantial flotation costs will be paid to investment bankers (Crutchley \& Hansen, 1989). As such, firms may find that it is optimal to utilize the combination of debt and dividend as well as managerial ownership to control agency conflicts in the firm.

\subsection{The Interrelationship between Managerial Ownership and Leverage}

Leland and Pyle (1977), Kim and Sorensen (1986), Stulz (1988) argued for a positive relationship between managerial ownership and leverage. Firms with higher managerial ownership have greater debt ratios than firms with lower managerial ownership to avoid the costs of external equity. The use of debt will reduce the need for external sources and thus increase the percentage of managerial ownership. Alternatively, owners of high managerial ownership firms may try to avoid diluting their control over the firm by issuing more debt (Kim \& Sorensen, 1986). On the other hand, findings of Agrawal and Mandelker (1987) study implicate that the higher is the managerial ownership, the greater is managers' willingness to accept the financial risk associated with an increase in financial debt.

On the other hand, Friend and Lang (1988), Jensen et al. (1992), Bathala et al. (1994), Chen and Steiner (1999) argued that higher managerial ownership will decrease leverage. Managers who have ownership in a firm with high debt ratios tend to suffer from higher risk than do owners. At one end of the spectrum, managers will face with the high risk of losing job when the company uses high level of debt. At the other end of the spectrum, the risk of bankruptcy increases with excessive use of debt and accordingly reduces the value of firms. Consequently, managers will strive for reducing the risk of losing job and personal wealth in their own portfolio by decreasing debt.

Based on these theoretical and empirical works, the study hypothesizes that:

Hypothesis $\mathbf{H}_{1}$ : There is a negative relationship between managerial ownership and leverage.

\subsection{The Interrelationship between Managerial Ownership and Dividend Payout}

Empirical studies, such as Rozeff (1982), Jensen et al. (1992), Eckbo and Verma (1994), generally found that a relationship between managerial ownership and dividend payout is negative. It means that firms with higher managerial ownership tend to increase internal funds at the expense of low dividend payouts in order to finance investments. Jensen (1986) also provided evidence that managers are reluctant to pay dividend. Alternatively, Chen and Steiner (1999), Kim et al. (2007) explained that both managerial ownership and dividends resolve 
agency problems. Therefore, managerial ownership and dividends may be thought of as substitute mechanisms geared at reducing agency costs, then it will be ineffective to use two tools at the same time to solve the same problem. Lower dividend will increase the probability that a firm engages in managerial ownership program and vice versa.

On a ground of the above analysis, a research hypothesis is developed as below:

Hypothesis $\mathbf{H}_{2}$ : There is a negative relationship between managerial ownership and dividend payout.

\subsection{The Interrelationship between Leverage and Dividend Payout}

According to Pecking Order Theory, firms prefer to fund projects with its retained earnings (Myers \& Majluf, 1984). If a firm pays out significant amount of dividend, this will lead to the decrease in free cash flow and then to raise the need for additional sources of external financing to maintain its optimal capital structure (Emery \& Finnerty, 1997; Easterbrook, 1984). Furthermore, debt was found to be positively related with dividend payout when both can be used to send a strong positive signal to outsiders to enhance the firm's value and to maintain access to capital market (Myers \& Frank, 2004).

On the contrary to the positive perspective, Jensen et al. (1992), Faccio, Lang and Young (2001) provided the negative relationship between leverage and dividends. A firm acquiring debt will have fixed financial charges, interests and repayment of principals and thus leads the firm into liquidation. As a consequence, the firm has tendency to pay lower dividends to maintain good liquidity position and cash flow. In adapting the Agency Theory argument, Rozeff (1982), Jensen (1986), Faccio et al. (2001) concluded that debt and dividend may be a substitute mechanismin reducing free cash flow that may be misused by managers.

In view of the Agency Theory, the research hypothesis is formed as below:

Hypothesis $\mathbf{H}_{3}$ : There is a negative relationship between leverage and dividend payout.

In short, the discussion on the interrelationship between managerial ownership, leverage and dividend is summarised by Figure 1 .

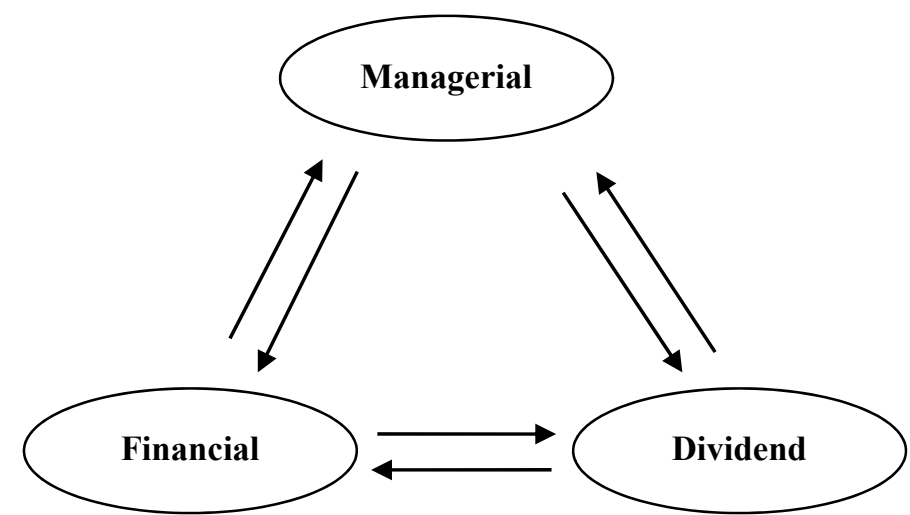

Figure 1. The interrelationship between managerial ownership, leverage and dividend policies

\section{Sample and Methodology}

The review of the empirical studies presents the role of managerial ownership, leverage and dividends, as mechanisms controlling agency conflicts in the firm. Jensen et al. (1992), Chen and Steiner (1999), Kim et al. (2007) suggested that firms can minimize the costs created by asymmetric information and misaligned incentives by optimizing jointly over managerial ownership, leverage and dividend payout policies. It is therefore useful to spread knowledge on this topic and to identify systematic tradeoffs in these policies in different environment such the one of Vietnam.

\subsection{Sample Selection}

A sample consists of 81 firms listed on Ho Chi Minh Stock Exchange (HOSE) over the period 2007-2012 with total 486 observations. This research was conducted using only secondary data, which were collected from different sources such as annual reports and financial statements of these 81 listed firms. All financial firms are excluded. Such as, banks, insurances and investment funds are subject to specific rules and regulations, thus capital structures of these firms are not comparable to the capital structures of firms in non-financial sector. 


\subsection{Methodology}

In a system comprising of independent endogenous variables, the 3SLS method is preferred over the ordinary least squares (OLS) method as the latter would lead to biased and inconsistent parameter estimates. The 3SLS method is the combination of two-stage least squares (2SLS) and Seemingly Unrelated Regression (SUR). This is used in a system of equations which are endogenous (Zellner \& Theil, 1962). This is not the case because managerial ownership, leverage and dividends are exogenous to the system. As long as the system of equations is properly identified, 3SLS provides estimates which are more consistent and efficient in the presence of simultaneity bias. Moreover, if the error terms in each regression are heteroskedastically linked, 3SLS will produce more efficient estimates (Greene, 2003). More importantly, the approach adopted in this study is an improvement over the single equation models employed in some studies that examine managerial ownership (Vo \& Phan, 2013), debt structure (Titman \& Wessels, 1988) and dividend payout policy (Rozeff, 1982). On the other hand, studies by Jensen et al. (1992), Chen and Steiner (1999), Dutta (1999), Kim et al. (2007) employ a simultaneous equations approach with managerial ownership, leverage and dividend policy as the endogenous variables.

Based upon the literature review and previous empirical studies of the interrelationships among the agency-cost-reducing mechanisms, all estimations in this study are undertaken with 3SLS regression method in STATA. While managerial ownership, debt and dividends are defined as dependent variables of each equation, other variables are defined as exogenous variables and taken to be instrumental variables for predicting the endogenous variables.

The specification of the simultaneous equations system is defined by equation (1)-(3) as below:

$$
\begin{aligned}
& M G O_{i, t}=\alpha_{0}+\alpha_{1} L E V_{i, t}+\alpha_{2} D I V R_{i, t}+\alpha_{3} F C F_{i, t}+\alpha_{4} G R O_{i, t}+\alpha_{5} S I Z E_{i, t}+\varepsilon_{i, t} \\
& L E V_{i, t}=\beta_{0}+\beta_{1} M G O_{i, t}+\beta_{2} D I V R_{i, t}+\beta_{3} F C F_{i, t}+\beta_{4} L I Q_{i, t}+\beta_{5} S I Z E_{i, t}+\vartheta_{i, t} \\
& D_{I V R}=\gamma_{i, t}+\gamma_{1} M G O_{i, t}+\gamma_{2} L E V_{i, t}+\gamma T A N G_{i, t}+\gamma_{4} G R O_{i, t}+\gamma_{5} R O A_{i, t}+\xi_{i, t}
\end{aligned}
$$

with

- $\quad \mathrm{i}=1,2, \ldots, 81$ and $\mathrm{t}=2007,2008, \ldots, 2012$

- $\quad$ i: number of firms

- $t$ : the estimation period

where: MGO as managerial ownership, LEV as financial leverage, DIVR as dividend payout, FCF as free cash flow, LIQ as liquidity, GRO as sales growth, ROA as profitability; TANG as fixed assets, and SIZE as firm size.

\subsection{Measurement of Variables}

\subsubsection{Equation 1: Managerial Ownership Equation}

The explanatory variables for the managerial ownership equation include free cash flow (FCF), sales growth (GRO), and firm size (SIZE).

Easterbrook (1984) and Jensen (1986) emphasized that the substantial free cash flow is the core of agency problems between managers and shareholders. In this case, several empirical researches argued for managerial ownership as evident solution to agency conflicts that aligns interests of managers on those of shareholders. Lange and Sharpe (1995), Himmelberg, Hubbard and Darius (1999) found the positive impact of free cash flow on the proportion of shares held by managers. Based on the argument, a negative coefficient for FCF is hypothesized.

GRO represents sales growth and is anticipated to have a positive impact on managerial ownership. Under asymmetric information, the past sales growth reflects future profitability and potential development. As such, managers would be less reluctant to invest in the firm's equity (Leland \& Pyle, 1977). The positive relationship between growth and managerial ownership could stem from informational advantages to insiders about growth prospects of the firm (Bathala et al., 1994). Consequently, a positive coefficient is hypothesized for the GRO variable.

A firm size variable, SIZE, is measured as the natural $\log$ of total assets of the firm at the end of the year. Previous studies reported that managerial ownership is significantly greater in smaller firms than in larger firms. As the firm gets larger, managerial risk aversion and constraints on managerial wealth limit the willingness of managers to increase their ownership (Bathala et al., 1984; Crutchley \& Hansen, 1989; Jensen et al., 1992). Therefore, a negative coefficient for SIZE is expected. 


\subsubsection{Equation 2: Leverage Equation}

For the leverage equation, the regressor includes free cash flow (FCF), liquidity (LIQ) and firm size (SIZE). Jensen (1986) suggested that in the case of low growth opportunities, the greater agency costs are generated as free cash flow rises; hence, debt financing should be employed. Stluz (1990) also reported a positive relationship between leverage and free cash flow. As such, a positive coefficient is hypothesized for the FCF variable.

Liquidity, LIQ, is calculated as the ratio of current assets over current liabilities. In explaining the LIQ variable, Miller and Rock (1985) argued that firms prefers internal sources (such as available liquidity assets) to leverage. Thus, a firm's liquidity position should have a negative impact on its leverage ratio. Similarly, Myers and Majiluf (1984), Friend and Lang (1988), Kim et al. (2007) reported that firms with highly liquid assets can use such assets to finance their investments. On the ground of these studies, the study hypothesizes that there is a negative relationship between asset liquidity and the leverage.

Theoretically, larger firms are more diversified than smaller ones and less prone to bankruptcy, making them able to accept high debt ratios (Rajan \& Zingales, 1995). Another explanation is that majority of large firms in Vietnam are state-controlled firms. Indeed, state-controlled companies seem to access bank loans more easily than other companies. This argument would also suggest a positive coefficient for the SIZE variable.

\subsubsection{Equation 3: Dividend Equation}

Tangibility (TANG), sales growth (GRO) and profitability (ROA) are included as the explanatory variables in the dividend equation.

The TANG variable is measured as the ratio of the book value of fixed assets to the book value of total assets. Titman and Wessels (1988), Aivazian, Booth and Cleary (2003) suggested that there is a negative relationship between asset tangibility and dividend payout. The more the tangible assets in the firm will lead the lower the size of the short-term assets which may serve as collateral against debt financing. Therefore, firms will depend more on their retained earnings, which means that the lower the chance to pay dividends. This argument would propose a negative coefficient for the TANG variable.

The sales growth, GRO, is found to have negative influence to dividend payout (Jensen et al., 1992). In the view of Pecking Order Theory, firm tended to use internal funding sources to finance investment projects. If a firm has large growth opportunities and large investment projects, it chooses to cut or pay lower level of dividends to reduce its dependence on costly external financing. According to Agency Theory, firms with slow grow opportunities have high free cash flow, so paying dividends play an incentive role in reducing agency cost of free cash flow (Rozeff, 1982; Jensen, 1986). Consequently, sales growth is expected to be negative related to dividend payout.

The profitability variable, ROA, is defined as the income before tax divided by the book value of total assets. In previous studies, it is considered as an important explanatory variable of dividend policy (Fama \& French, 2001). It is argued that there is a positive relationship between the profitability of the firm and dividend payments. Signaling Theory supports this relationship. As such, profitable firms are more likely to pay dividends (Miller \& Rock, 1985; Jensen et al., 1992). Therefore, a research hypothesizes that there is a positive relationship between profitability and dividend payout.

Concepts and measurements of these variables are summarized in Table 1.

Table 1. Definition and measurement of the variables

\begin{tabular}{|c|c|c|}
\hline Variables & Definition & Measurement \\
\hline \multicolumn{3}{|c|}{ Dependent variables } \\
\hline MGO & Managerial ownership & Number of shares held by directors and members of the board / total outstanding shares \\
\hline LEV & Leverage & Book value of total debt/ Book value of total assets \\
\hline DIVR & Dividend payout & Dividend payout/Sales \\
\hline \multicolumn{3}{|c|}{ Explanatory variables } \\
\hline FCF & Free cash flow & {$[$ EBIT* $(1-$ tax $)+$ depreciation - change in working capital - expenditure]/ (total assets) } \\
\hline LIQ & Liquidity & Current assets/Current liabilities \\
\hline GRO & Sales growth & $\left(\mathrm{Sales}_{\mathrm{t}}-\mathrm{Sales}_{\mathrm{t}-1}\right) / \mathrm{Sales}_{\mathrm{t}-1}$ \\
\hline ROA & Profitability & Earnings before tax/ Total assets \\
\hline TANG & Fixed assets & Tangible assets/ Total assets \\
\hline SIZE & Firm Size & Log(total assets) \\
\hline
\end{tabular}




\section{Empirical Results}

\subsection{Descriptive Statistics}

Table 2 presents the summary statistics of all the variables in the model. First, managers, on average, own approximately $0.2958(29.58 \%)$ of the firms' shares with standard deviation of $0.2314(23.14 \%)$. The mean is considerably higher than the level of managerial ownership in firms listed in U.S market (Jensen et al., 1992; Chen \& Steiner, 1999; Dutta, 1999).

Second, the book value of leverage ranges from 0.039 to 0.9111 (from $3.9 \%$ to $91.11 \%$ ) while the mean value is $0.4721(47.21 \%)$. This indicates that some of firms are heavily reliant on debt financing.

Finally, payout ratio has a mean value of $0.0552(5.52 \%)$ with a standard deviation of $0.0828(8.28 \%)$. Minimum and maximum value of dividend payment are respectively $0.00(0 \%)$ and $0.6824(68.24 \%)$.

Table 2. Descriptive statistic of variables

\begin{tabular}{llllll}
\hline Variables & $\begin{array}{l}\text { Number of } \\
\text { observations }\end{array}$ & Mean & Std. Dev. & Minimum & Maximum \\
\hline MGO & 486 & 0.2958 & 0.2314 & 0.0011 & 0.9615 \\
LEV & 486 & 0.4721 & 0.2136 & 0.0390 & 0.9111 \\
DIVR & 486 & 0.0552 & 0.0828 & 0.0000 & 0.6824 \\
ROA & 486 & 0.1002 & 0.0975 & -0.6473 & 0.5245 \\
FCF & 486 & 0.0469 & 0.1430 & -0.6570 & 0.5645 \\
LIQ & 486 & 2.1399 & 1.4547 & 0.1638 & 8.4021 \\
TANG & 486 & 0.1852 & 0.1693 & 0.0007 & 0.9356 \\
GRO & 486 & 0.2066 & 0.3825 & -0.6862 & 2.9994 \\
SIZE $\left(10^{6}\right)$ & 486 & $1,460,091$ & $2,483,348$ & 94,498 & $19,697,868$ \\
\hline
\end{tabular}

Source: Authors' calculations.

Table 3 reports a correlation matrix between dependent variables and explanatory variables. The outcomes present that most correlations of variables are small, which indicates multicollinearity does not seem to pose a serious problem in the study. Noticeably, none of the correlation coefficients for pair of managerial ownership, leverage and dividends go beyond -0.4 or +0.4 . This implies that the interdependence among the three variables does not arise from the spurious correlation.

Table 3. A correlation matrix among variables

\begin{tabular}{|c|c|c|c|c|c|c|c|c|c|}
\hline & MGO & LEV & DIVR & ROA & FCF & LIQ & TANG & GRO & SIZE \\
\hline MGO & 1 & & & & & & & & \\
\hline LEV & 0.141 & 1 & & & & & & & \\
\hline DIVR & 0.108 & -0.352 & 1 & & & & & & \\
\hline ROA & -0.034 & -0.589 & 0.333 & 1 & & & & & \\
\hline FCF & 0.135 & -0.099 & 0.060 & 0.167 & 1 & & & & \\
\hline LIQ & -0.014 & -0.713 & 0.299 & 0.440 & -0.048 & 1 & & & \\
\hline TANG & 0.249 & -0.030 & 0.029 & -0.074 & 0.118 & 0.006 & 1 & & \\
\hline GRO & -0.011 & -0.024 & -0.023 & 0.237 & -0.021 & 0.039 & -0.050 & 1 & \\
\hline SIZE & 0.345 & 0.267 & 0.047 & -0.012 & 0.049 & -0.058 & 0.180 & 0.002 & 1 \\
\hline
\end{tabular}

Source: Authors' calculations.

\subsection{Regression Results}

Table 4 shows the interdependence analysis of managerial ownership, leverage and dividend using the 3SLS estimation. 
Table 4. The 3SLS regression results

\begin{tabular}{llll}
\hline Explanatory & \multicolumn{3}{c}{ Dependent variables } \\
\cline { 2 - 4 } variables & MGO $(1)$ & LEV $(2)$ & DIVR $(3)$ \\
\hline Constant & -0.8891 & $-0.8735 * * *$ & $0.0676^{* * *}$ \\
MGO & & $-\mathbf{0 . 9 0 9 7 * * *}$ & $\mathbf{0 . 1 4 5 9 * * *}$ \\
LEV & -0.4154 & & $\mathbf{- 0 . 1 2 3 0 * * *}$ \\
DIVR & -2.2062 & $\mathbf{- 4 . 0 6 5 3 * * *}$ & \\
FCF & $\mathbf{0 . 2 3 6 0 * * *}$ & $\mathbf{0 . 2 0 4 1 * * *}$ & \\
SIZE & $\mathbf{0 . 2 5 2 9 * * *}$ & $\mathbf{0 . 3 2 1 5} * * *$ & \\
GRO & 0.0079 & & -0.0082 \\
LIQ & & $\mathbf{- 0 . 0 3 0 1 * *}$ & \\
ROA & & & $\mathbf{0 . 1 4 7 0 * * *}$ \\
TANG & & $-\mathbf{0 . 0 5 6 4 * *}$ \\
No. & 486 & 486 & 486 \\
R & -0.5886 & -2.4448 & 0.1137 \\
\hline
\end{tabular}

Note. ${ }^{* * *} \mathrm{p}<0.01 ; * * \mathrm{p}<0.05 ; * \mathrm{p}<0.1$.

Source: Authors' calculations.

In some of the 3SLS estimations, $\mathrm{R}^{2}$ is negative and thus $\mathrm{R}^{2}$ is not usable in 3SLS as the model in 3SLS focuses more on structural relationship (Gujarati, 2003; Sribney, Wiggins, \& Drukker, 2011).

\subsubsection{Managerial Ownership Equation}

Table 4 (column 1) shows the results of regression analysis between leverage (LEV), dividend (DIVR) and other explanatory variables to managerial ownership (MGO). Both coefficients of the LEV variable and DIVR variable show the negative but insignificant to the MGO variable $(\mathrm{p}>0.1)$. It shows that the increasing of debt and dividend payment will cause the decreasing of managerial ownership but insignificant. In the context of controlling, it means that the role of managerial ownership could be substitute for leverage and dividend in the mechanism of controlling agency conflicts.

Expectedly, the positive coefficient of free cash flow variable (FCF) is consistent with the hypothesis that the increasing of free cash flow will induce the increase of managerial ownership for controlling agency costs. However, a significant positive effect of firm size variable (SIZE) on MGO indicates that managers tend to increase their ownership when firm size becomes larger. In addition, the coefficient of the grow level variable (GRO) shows the positive relationship with the MGO variable but insignificant $(0.0079 ; \mathrm{p}>0.1)$.

\subsubsection{Leverage Equation}

In the equation with leverage as dependent variable, the relation with managerial ownership and dividend are negative as expected and significant at the level of 1 per cent $(\mathrm{p}<0.01)$. This result supports the findings of Jensen et al. (1992) which proposed that managers with a major stake in a firm are less diversified and have more incentives to reduce financial risk. Furthermore, this also suggests that there is any substitution relationship between leverage and dividend in mechanism of controlling the agency conflicts.

Expectedly, the exogenous variables in the leverage equation are significant at the 0.01 and 0.5 level. The positive relation between FCF and LEV is supportive of the arguments by Jensen (1986) and Stulz (1990). The negative relation between LIQ and LEV is consistent with arguments of Kim et al. (2007). Lastly, the positive relation between SIZE and LEV is supportive conclusion of Rajan and Zingales (1995).

\subsubsection{Dividend Equation}

As shown in Table 4 (column 3), the coefficient of LEV variable is negative and significant at the level of 1 per cent $(-0.1230 ; \mathrm{p}<0.01)$, which is consistent with the hypothesis $\mathrm{H}_{3}$ as proposed. Surprisingly, the positive sign on the MGO variable suggests that higher ownership level leads to higher dividend. This result fails to support the second hypothesis that there is a negative relationship of managerial ownership and dividend. Among the three exogenous variables, the TANG variable is negative at the 5 per cent level of significance, the ROA variable is positive and significant at the level of 1 per cent, and the GRO variable is negative but insignificant.

\section{Conclusion and Implication}

The study investigates the relationship between managerial ownership, leverage and dividend policies. Unlike 
previous researches, the 3SLS approach is employed to estimate the system of structural equations. The results suggest that managerial ownership has negative impact on leverage and positive impact on dividend payout. Furthermore, dividend is negatively associated with leverage ratio. Lastly, the study finds that leverage and dividend has a negative relationship. However, the study partially fails to test that there is impact of managerial ownership on leverage and dividend.

The implication of this study are relevant to investors and firms that listed in HOSE. Managers have ownership in firms will suffer from higher risk than investors. One of causes of risk is debt; therefore, managers tend to increase their ownership to take control right affecting financial policies of firms. Especially, managers holding considerable number of shares in a firm will avoid the use of high leverage and even requiring more dividend payment to compensate for their financial risk. As a consequence, small investors are recommended to avoid firms that have high leverage or managerial ownership levels. In term of agency perspective, leverage and dividend policies can be used substitutes as internal mechanisms in reducing agency conflicts. This also implies that the precise policy is required to reduce agency conflicts to improve corporate governance quality in a firm.

\section{References}

Agrawal, A., \& Mandelker, G. (1987). Managerial Incentives and Corporate Investment and Financing Decisions. The Journal of Finance, 42(4), 823-837. http://dx.doi.org/10.1111/j.1540-6261.1987.tb03914.x

Aivazian, V., Booth, L., \& Cleary, S. (2003). Do emerging market firms follow different dividend policies from US firms? The Journal of Financial Research, 26(3), 371-387. http://dx.doi.org/10.1111/1475-6803.00064

Bathala, C. T., Moon, K. P., \& Rao, R. P. (1994). Managerial ownership, debt policy, and the impact of institutional holdings: An agency perspective. Financial Management, 23(3), 38-50. http://dx.doi.org/10.2307/3665620

Busenitz, L. W., Fiet, J. O., \& Moesel, D. D. (2005). Signaling in venture capitalist: new venture team funding decision; does it indicate long term venture outcomes? Entrepreneurship Theory and Practice, 29(1), 1-12. http://dx.doi.org/10.1111/j.1540-6520.2005.00066.x

Chen, C. R., \& Steiner, T. L. (1999). Managerial Ownership and Agency Conflicts: A Nonlinear Simultaneous Equation Analysis of Managerial Ownership, Risk Taking, Debt Policy and Dividend Policy. The Financial Review, 34(1), 119-136. http://dx.doi.org/10.1111/j.1540-6288.1999.tb00448.x

Crutchley, C. E., \& Hansen, R. S. (1989). A test of the agency theory of managerial ownership, corporate leverage and corporate dividends. Financial Management, 18(4), 36-46. http://dx.doi.org/10.2307/3665795

Crutchley, C. E., Jensen, M. R. H., Jahera, J. S. Jr., \& Raymond, J. E. (1999). Agency problem and the simultaneity of financial decision making. The role of institutional ownership. International Review of Financial Analysis, 8(2), 177-197. http://dx.doi.org/10.1016/S1057-5219(99)00011-3

Duc, V., \& Thuy, P. (2013). Corporate Governance and Firms Performance: Empirical evidence from Vietnam. Paper presented at the 42th Australian Conference of Economists Conference held by Murdoch University, Perth, Western Australia.

Dutta, A. S. (1999). Managerial ownership, dividend and debt policy in the US banking industry. Managerial Finance, 25(6), 57-68. http://dx.doi.org/10.1108/03074359910766019

Easterbrook, F. (1984). Two agency-cost explanations of dividend. American Economic Review, 74(4), 650-659.

Eckbo, B. S., \& Verma, S. (1994). Managerial Share ownership, Voting Power, and Cash Dividend Policy. Journal of Corporate Finance, 1(1), 33-62. http://dx.doi.org/10.1016/0929-1199(94)90009-4

Emery, D. R., \& Finnerty, J. D. (1997). Corporate Financial Management. Prentice Hall Inc.

Faccio, M., Lang, L. H., \& Young, L. S. F. (2000). Dividends and Expropriation. American Economic Review, 91(1), 54-78. http://dx.doi.org/10.1257/aer.91.1.54

Fama, E. F. (1980). Agency problem and the theory of the firm. Journal of Political Economy, 88(2), 288-307. http://dx.doi.org/10.1086/260866

Friend, I., \& Lang, L. H. P. (1988). An empirical test of the impact of managerial self-interest on corporate $\begin{array}{llll}\text { capital structure. The Journal of } & \text { Finance, 43(2), 282. }\end{array}$ http://dx.doi.org/10.1111/j.1540-6261.1988.tb03938.x

Greene, W. H. (2003). Econometric Analysis (5th ed.). New York, NY: Prentice Hall.

Gujarati, D. N. (2003). Basic Econometrics (4th ed.). Boston: Mc Graw-Hill. 
Himmelberg, C. P., Hubbard R. G., \& Darius, P. (1999). Understanding the determinants of managerial ownership and the link between ownership and performance. Journal of Financial Economics, 53(3), 353384. http://dx.doi.org/10.1016/S0304-405X(99)00025-2

Jensen, M. C. (1986). Agency Costs of Free Cash Flow, Corporate Finance and Takeovers. The American Economic Review, 76(2), 323-329.

Jensen, M. C., \& Meckling, W. H. (1976). Theory of the Firm: Managerial Behavior, Agency Costs, and Capital $\begin{array}{llll}\text { Structure. Journal of } & \text { Financial 305-360. }\end{array}$ http://dx.doi.org/10.1016/0304-405X(76)90026-X

Jensen, G. R., Solberg, D. P., \& Zorn, T. S. (1992). Simultaneous determination of insider ownership, debt and dividend policies. Journal of Financial and Quantitative Analysis, 27(2), 247-263. http://dx.doi.org/10.2307/2331370

Kim, S. W., \& Sorensen, E. H. (1986). Evidence on the impact of the agency cost of debt on Corporate Debt Policy. Journal of Financial and Quantitative Analysis, 21(2), 131-144. http://dx.doi.org/10.2307/2330733

Kim, Y. H., Rhim, J. C., \& Friesner, D. L. (2007). Interrelationship among Capital Structure, Dividends, and Ownership: Evidence from South Korea. Multinational Business Review, 15(3), 25-42. http://dx.doi.org/10.1108/1525383X200700011

Lange, H. P. \& Sharpe, I. G. (1995). Monitoring Costs and Ownership Concentration: Australian Evidence. Applied Financial Economics, 5(2), 441-444. http://dx.doi.org/10.1080/758538604

Leland, H. E., \& Pyle, D. H. (1977). Information asymmetries, financial structure, and financial intermediation. The Journal of Finance, 32(2), 371-387. http://dx.doi.org/10.2307/2326770

Miller, M., \& Rock, K. (1985). Dividend policy under asymmetric information. The Journal of Finance, 40(4), 1031-1052. http://dx.doi.org/10.1111/j.1540-6261.1985.tb02362.x

Morck, R., Shleifer, A., \& Vishny, R. (1988). Management Ownership and Market Valuation. Journal of Financial Economics, 20(1), 293-315. http://dx.doi.org/10.1016/0304-405X(88)90048-7

Myers, M., \& Frank, B. (2004). The Determinants of Corporate Dividend Policy. Academy of Accounting and Financial Studies Journal, 8(3), 17-28.

Myers, S. C. (1977). Determinants of corporate borrowing. Journal of Financial Economic, 5(2), 147-175. http://dx.doi.org/10.1016/0304-405X(77)90015-0

Myers, S. C., \& Majluf, N. S. (1984). Corporate financing and investment decisions when firms have information that investors do not have. Journal of Financial Economics, 13(2), 187-221. http://dx.doi.org/10.1016/0304-405X(84)90023-0

Rajan, R. G., \& Zingales, L. (1995). What do we know about capital structure? Some evidence from international data. The Journal of Finance, 50(5), 1421-1460. http://dx.doi.org/10.1111/j.1540-6261.1995.tb05184.x

Rozeff, M. S. (1982). Growth, beta and agency costs as determinants of dividend payout ratios. The Journal of Financial Research, 5(3), 249-259.

Ross, S. A. (1977). The Determination of Financial Structure: the Incentive-Signaling Approach. The Bell Journal of Economics, 8(1), 23-40. http://dx.doi.org/10.2307/3003485

Sribney, W., Wiggins, V., \& Drukker, D. (2011). Negative and missing R-squared for 2SLS/IV. Stata Corp.

Stulz, R. (1990). Managerial discretion and optimal financing policies. Journal of Financial Economics, 26, 2554. http://dx.doi.org/10.1016/0304-405X(90)90011-N

Sundaramurthy, C., \& Lewis, M. (2003). Control and collaboration: Paradoxes of governance. Academy of Management Review, 28(3), 397-415.

Titman, S., \& Wessels, R. (1988). The determinants of capital structure choice. The Journal of Finance, 43(1), 119. http://dx.doi.org/10.1111/j.1540-6261.1988.tb02585.x

Zellner, A., \& Theil, H. (1962). Three-stage least squares: simultaneous estimation of simultaneous equations. Econometrica, 30(1), 54-78. http://dx.doi.org/10.2307/1911287 


\section{Copyrights}

Copyright for this article is retained by the author(s), with first publication rights granted to the journal.

This is an open-access article distributed under the terms and conditions of the Creative Commons Attribution license (http://creativecommons.org/licenses/by/3.0/). 